\title{
DIE-BACK OF KIAAT (PTEROCARPUS ANGOLENSIS) IN SOUTHERN AFRICA: A CAUSE FOR CONCERN?
}

\author{
JWM Mehl $^{1}$, CJ Geldenhuys ${ }^{2}$, J Roux ${ }^{1}$, MJ Wingfield $^{1}$ \\ ${ }^{1}$ Department of Microbiology and Plant Pathology, Forestry and Agricultural Biotechnology Institute (FABI), \\ DST/NRF Centre of Excellence in Tree Health Biotechnology (CTHB), Faculty of Natural and Agricultural \\ Sciences, University of Pretoria, Pretoria, 0002, South Africa
}

${ }^{2}$ Department of Forest and Wood Science, University of Stellenbosch, c/o Forestwood cc, PO Box 228, La Montagne, 0184, Pretoria, South Africa

Corresponding author, e-mail: james.mehl@fabi.up.ac.za

Pterocarpus angolensis (kiaat) is a well-known Southern African tree species of commercial importance that occurs in several vegetation types in the Zambezian regional centre of endemism. The most prominent of these vegetation types are the Zambezian miombo woodland and undifferentiated woodland. A diverse range of ecosystems within these vegetation types necessitate adaptation by tree species to survive extremes of drought, temperature, altitude, soil nutrition and tolerate fire in order to compete with other plant species. There are several reports of a die-back disease of $P$. angolensis in Zambia, Zimbabwe and South Africa, but very little is known regarding the cause or significance of this problem. In this review, we provide details regarding the history of the disease and consider its possible causal agents. A pathology study conducted in three locations in South Africa on diseased and dying trees resulted in the collection of 199 fungal isolates; comprising saprophytic species such as Candida, Penicillium and Humicola, and potentially pathogenic species such as Lasiodiplodia theobromae, Cytospora spp. and Fusarium spp. Drought, during several years preceding disease, along with a lack of fire management may have contributed to both the present and past reports of tree die-back and death. Finally, an analysis is made of the importance of the problem and actions that might be taken to alleviate it. 


\section{KEYWORDS}

mukwa disease; Fusarium oxysporum; drought; stand-level die-back; Fusarium; Cytospora; Lasiodiplodia theobromae; fire management

\section{INTRODUCTION}

Pterocarpus angolensis (kiaat) is a well-known Southern African tree species valued for its timber (Lowore 1993) and use in several traditional medicinal applications (Coates Palgrave 1977). In South Africa, the species is protected by state law (Krynauw 1998) while in Tanzania a minimum stem diameter at breast height (DHB) is prescribed to limit harvesting of small trees (Caro et al. 2005). Despite these efforts, the species is under threat. Size prescriptions are ignored in some areas of Tanzania (Caro et al. 2005), past and present exploitation has raised concerns of the extinction of $P$. angolensis in Zimbabwe (Mushove 1991, Bradley and Dewees 1993, Clarke et al. 1996) and availability reported by woodcarvers in South Africa indicates that trees are becoming rare (Steenkamp 1999). These concerns are underscored by low seedling recruitment rates during both germination and the suffrutex stage (Boaler 1966, Schwartz et al. 2002, Caro et al. 2005) and by unsustainable rates of harvesting (Schwartz et al. 2002, Caro et al. 2005).

Pterocarpus angolensis occurs in several vegetation types in the Zambezian regional centre of endemism. The most prominent of these are the Zambezian miombo woodland, which includes both wetter and drier miombo, and the more species-rich north and south undifferentiated woodland (White 1983). These vegetation types span a range of ecosystems that differ with respect to fire, frost and drought tolerance. Pterocarpus angolensis is, therefore, adapted to survive and tolerate extremes stemming from several environmental factors, including fire, drought and moisture availability. The species can 
tolerate an annual rainfall as low as $500 \mathrm{~mm}$ (van Wyk 1972) and as high as $1250 \mathrm{~mm}$ (Von Breitenbach 1973), average temperatures as low as $4^{\circ} \mathrm{C}$, and altitudes ranging from sea-level to $1650 \mathrm{~m}$ above sea-level (Von Breitenbach 1973). The soils of both miombo woodland (Högberg 1992) and undifferentiated woodland (Scholes and Walker 1993) are poor in organic matter, nitrogen and phosphorus but $P$. angolensis possesses both vesicular-arbuscular (VA) mycorrhizae (Munyanziza and Oldeman 1995) and functional nitrogen fixing root nodules (Boaler 1966, Chrizelle Beukes FABI University of Pretoria, pers. comm.), ensuring that the species is able to efficiently utilize available nutrients. The species cannot tolerate competition with dense grass and dense stands of trees and regeneration is favoured by regular fire (Boaler 1966, Geldenhuys 1977).

Despite the adaptations of $P$. angolensis to relatively harsh environments, there are several reports dating back to the late 1950s of these trees becoming diseased and dying (Anonymous 1973, Piearce 1979, van Wyk et al. 1993, Mushove 1996, Krynauw 1998, 2000). These reports refer to trees in the Livingstone district between Livingstone in Zambia and Bulawayo in Zimbabwe, as well as in several areas of South Africa. In this review, we discuss disease symptoms observed and the possible reasons for tree death, including ecological conditions that might predispose trees to diseases. Furthermore, advice is provided regarding management options for diseased $P$. angolensis trees and possible strategies that may help to alleviate the disease.

\section{THE SITUATION IN THE LIVINGSTONE AREA, ZAMBIA AND ZIMBABWE}

\section{Disease of $\boldsymbol{P}$. angolensis trees}

In 1958, a disease resulting in the death of $P$. angolensis trees west of Livingstone, Zambia, was reported. Subsequently in 1964, additional affected trees were found in the 
Kalahari Sands/Zambezi Teak Forests (Anonymous 1973). By July 1964, the disease was reported close to the Victoria Falls village in Zimbabwe, and thereafter it was noted more widely (Geary 1972, Anonymous 1973). In March 1966, the disease was reported in the Bambezi Forest Reserve, about 100 km north-west of Bulawayo (Piearce 1979). Calvert (1972), produced evidence indicating that there had been earlier reports of the disease in Botswana in the early 1930s, in Zambia in the late 1940s and early 1950s, and in Zimbabwe in the early 1930s, late 1940s and early 1950s (Piearce 1979). Since then, the disease has become localized in the border area between Botswana, Zimbabwe and Zambia resulting in stand-level die-back in this area (van Wyk et al. 1993). The disease was named "mukwa disease", referring to one of the common names (mukwa) given to $P$. angolensis.

Mukwa disease has a range of symptoms, the most prominent being blight and die-back of affected trees (Calvert 1972, Piearce 1979, 1986). Other symptoms include a generally unhealthy appearance of the crown foliage, wilt and chlorosis (Calvert 1972, Piearce 1979, 1986). Defoliation, desiccation, the occurrence of epicormic buds on the healthy parts of the tree trunks and branches and premature development of new leaves are common symptoms. The bark discolors from brown to grey, cracks or flakes, and can be peeled off in large flaps, and xylem and sapwood become stained. Xylem/sapwood streaks are a dull blue-grey or orange-red in colour and appear as complete flecked rings or discontinuous arcs. In microtome sections, xylem vessels contain amorphous deposits, occlusions, and fungal hyphae (Piearce 1979). Vascular streaking appears to originate from several points in the root system or from a single rotten root (Piearce 1979). Van Wyk et al. (1993) noted that phloem streaking was often emphasized in affected trees and this appears to be a distinguishing factor on affected trees (Calvert 1972, Piearce 1979, 1986). The most intensive symptoms are observed at the height of the rainy season. Diseased trees typically occur in patches and usually die within two to three years (Calvert 1972, Piearce 
1979, 1986).

\section{Possible causes of mukwa disease}

Mukwa disease has been attributed to Fusarium oxysporum Schltdl. based on the consistent isolation of this fungus from discolored wood (Piearce 1979, 1983, 1986, van Wyk et al. 1993). Fusarium oxysporum is a well-known pathogen, causing wilt diseases, damping off and crown and root rots of a wide variety of plants (Leslie and Summerell 2006). It has also been recorded as a wilt and die-back pathogen of several leguminous tree species, including Acacia koa and Albizia julibrissin (Anderson et al. 2002), and was recently associated with cankers on Cedrelinga cateniformis in the Amazon basin (Lombard et al. 2008). The fungus is typically associated with plant roots and Gordon and Martyn (1997) suggest that either the fungus grows beyond the cortex into the xylem to initiate plant disease or that it already exists as an endophyte within affected plants. Strains of the fungus are often non-pathogenic in nature and it is more likely that some change, either physiological or biological, in the host or the fungus allows disease to develop (Gordon and Martyn 1997).

Drought has been mentioned in every report of mukwa disease and stress might be an important factor in its development (Calvert 1972, Geary 1972, Anonymous 1973, Piearce 1979, 1986). For example, affected trees in Matabeleland in Zimbabwe experienced 12 consecutive seasons of poor rainfall up to 1973 (Anonymous 1973). Rainfall data from the South African Weather Bureau for the area (Figure 1), from the two closest weather stations (Bulawayo in Zimbabwe and Livingstone in Zambia), based on World Weather Records (vol. 5: Africa) for 1951 to 1980 (Anonymous 1967, 1979, 1987) show a correlation between annual rainfall in the area and mukwa disease. From 1958 to 1959, there was a drop in rainfall at Livingstone from $1410 \mathrm{~mm}$ to $620 \mathrm{~mm}$, which is considerably 
lower than the average of $\sim 800 \mathrm{~mm}$ in preceding years. In general, rainfall remained at this level at both weather stations until 1965, other than in 1962 when $1078 \mathrm{~mm}$ of rainfall was recorded in Livingstone. From 1972, rainfall improved at Livingstone. Outbreaks of Mukwa disease were reported in Zimbabwe in 1958/9, 1964, 1966, 1967 and 1968 (Calvert 1972, Piearce 1979) and this is supported by the low rainfall reported (Figure 1) in Bulawayo. From 1973 to 1977 , the disease was studied at Livingstone by Piearce (1979) and it is likely that his observations centred on trees that were dying from the sustained drought period of previous years.

\section{Insert Figure 1}

Fire is a critical factor in the ecology of $P$. angolensis that has frequently been overlooked or ignored in studies on mukwa disease. It positively influences individuals of $P$. angolensis by suppressing competition for nutrients and water in the soil and demand and competition for sunlight and space. The species is a pioneer in areas where fire has occurred (Von Breitenbach 1973). Seed germination is dependent on the removal of the underlying grassy layer and the wings and bristles of the fruit by a "cold" fire enabling seed to come into contact with the ground (Von Breitenbach 1973, van Daalen 1991), and subsequent exposure to rain (Boaler 1966). Seedlings of the species produce an extensive, although shallow (Geldenhuys 1977), underground root system in several successive years of annual die-back (the so-called suffrutex stage) to collect sufficient water and nutrients for stem production (Boaler 1966, Von Breitenbach 1973, Vermeulen 1990, Lowore 1993) and to survive subsequent fires (Vermeulen 1990). Fire also benefits $P$. angolensis by suppressing competing plant species and by eliminating root competition for soil water and nutrients from neighbours (probably exacerbated by the shallow root system of the species), helping to prune side-branches and secondary stems and releasing nutrients in the form of ash (Boaler 1966, Orpen 1982, Vermeulen 1990). In fact, 
both Boaler (1966) and Von Breitenbach (1973) noted positive growth effects from fire. Boaler (1966) reported an increase of $20 \%$ in sapling shoot length after burning of the herbaceous layer and Von Breitenbach (1973) noted a rapid increase in trunk diameter and crown size following removal of competing dense grass and scrub. Saplings are also light-demanding, developing a zig-zag appearance to maximize absorption, and fire eliminates competition for sunlight from neighbouring plants (Boaler 1966, Orpen 1982, Vermeulen 1990). A lack of sunlight results in shorter shoot length, a greater proportion of annual shoot die-back (Boaler 1966, Vermeulen 1990) and eventual death (Groome et al. 1957, Vermeulen 1990). Consequently, many reports of mukwa disease may easily be explained by a lack of fire and/or fire management in areas where $P$. angolensis occurs.

Several other tree species in the same stands, including Burkea africana, Erythrophleum africanum, Lannea schweinfurthii var. stuhlmanni, Strychnos cocculoides and Terminalia sericea (the most severely affected), have also been reported to be suffering from die-back and death (Anonymous 1973, Piearce 1979). Of these B. africana (Burke 2006, Holdo and Timberlake 2008), E. africanum (Holdo and Timberlake 2008) and T. sericea (Geldenhuys 1977, Rutherford 1983, Yeaton 1988, Holdo and Timberlake 2008) are known to have shallow root systems. In contrast, S. cocculoides has a deep rooting system but is physiologically limited in that there are almost no fine or adventitious roots in the first 20 $\mathrm{cm}$ of soil and this low root surface area density continues at lower soil levels (Oppelt et al. 2005). Several of these species are known to be tolerant to fire, including $B$. africana (Burke 2006), E. africanum (Lawton 1978), L. schweinfurthii var. stuhlmanni (Simute et al. 1998) and T. sericea (Strang 1974, Yeaton 1988). Like P. angolensis, some species are ecological pioneers, including E. africanum (also light-demanding) (Lawton 1978), L. schweinfurthii var. stuhlmanni (Welch 1960), S. cocculoides (light-demanding) (Hines and Eckman 1993) and T. sericea (light-demanding) (Strang 1974, Yeaton 1988). Consequently, all of these species share many physiological requirements with $P$. 
angolensis and reports of symptoms similar to those of mukwa on these trees are not surprising.

Based on the observation that trees follow a cyclic pattern in response to the disease, Calvert (1986) proposed that mukwa disease is a form of stand-level die-back that encourages regeneration. Indeed, Piearce (1983) noted that mukwa disease was beginning to wane, based on a decrease in the rate of new infections and the recovery of some affected trees. This was confirmed by Mushove (1996) who concluded that mukwa disease is episodic. Also, van Wyk et al. (1993) noted an increase in saplings as mukwa disease progressed, indicating species regeneration, and that the disease affected older trees (with larger diameters) rather than young trees.

The stand-level die-back of $P$. angolensis in the Kalahari Sands/Zambezi Teak Forests has been compared to stand-level die-back of Metrosideros polymorpha (Myrtacae) trees in Hawaii (Ohia disease) (van Wyk et al. 1993). In the case of M. polymorpha, it has been suggested that die-back is related to primary succession and that the establishment of seedlings and sapling maturation is strongly related to the degree of opening in the forest canopy (Jacobi et al. 1983). This is consistent with the cohort senescence theory where many large cohorts/groups of individuals of the same (woody) plant species are established non-uniformly (a patchy distribution) in an area after a catastrophe or a decrease in the forest canopy (Mueller-Dombois 1983, 1986). These cohorts eventually begin to senesce/age from the effect of one or more environmental stresses that are either abiotic or biotic. Similarly, cohorts occurring in areas exposed to the same environmental stress/stresses can begin to senesce at the same time. At this stage a fluctuating/variable environmental site factor begins to contribute to stand-level die-back as its intensity increases over time. The resulting stress predisposes trees to attack by other biotic agents that begin to cause rapid decline or die-back. If trees manage to temporarily recover 
following the environmental site factor, these biotic agents can cause a lingering decline or die-back (Mueller-Dombois 1983, 1986). Drought, a lack of fire and $F$. oxysporum are considered possible contributors to stand-level die-back of $P$. angolensis (van Wyk et al. 1993).

\section{THE SITUATION IN SOUTH AFRICA}

\section{Reports of die-back of $P$. angolensis}

In South Africa, P. angolensis trees were first reported dying by Krynauw $(1998,2000)$ in the Mawewe Nature Reserve/Cattle Game Project, close to Malelane, in the east of the country. Recruitment of tree seedlings was low (Krynauw 1998, 2000), indicating that the species was not sustaining itself and raising further alarm regarding its conservation. Although the reserve has a number of giraffe, nyala, kudu and impala; livestock husbandry with cattle is also practised on the reserve (Krynauw 1998). Coppice regrowth of trees is likely inhibited by grazing of cattle (Desmet et al. 1996). Fire management is not practised on the reserve due to the risk it poses to cattle and the potential effects it may have on their grazing (Phumzile Khosa, reserve manager of Mawewe Nature Reserve and Cattle Game Project, Mpumalanga Parks Board, pers. comm.). When fires do occur, typically every five to six years, they are extremely intense.

Krynauw (1998), mentioned that $P$. angolensis trees had been reported dying near Bushbuckridge due to the 1991/2 drought in the area (C. M. Shackleton, University of the Witwatersrand, 1998, pers. comm.). The effects of this drought had also been noticed on trees in the nearby Kruger National Park (Viljoen 1995, Krynauw 1998). In particular, Viljoen (1995) found that although only $16 \%$ of trees greater than $8 \mathrm{~m}$ in height were dead at the Napi area in the Kruger National Park, $80 \%$ of the total tree population had less than 
$10 \%$ growth, based on assessments of coppice, a single living branch, or a stem or shoot sprouting from the roots, although even coppicing was poor. In the Pretoriuskop area, Viljoen (1995) noted that survival was considerably better and only $21 \%$ of the trees sampled had drought-induced damage of more than $50 \%$. In addition to the reports from the Kruger National Park and Mawewe, John Burrows (reserve manager of Buffelskloof Nature Reserve, Lydenburg, pers. comm.) reported that $P$. angolensis trees on that reserve appeared unhealthy.

\section{Observations from a pathology study (2005)}

To determine whether the reports of disease and death of $P$. angolensis in South Africa were similar to mukwa disease, samples from trees in three locations in the Mpumalanga Province of South Africa (Figure 2) were collected during November and December 2005. Samples of diseased material were collected from trees at Mawewe Nature Reserve (near Malelane) (7 trees) and Buffelskloof Nature Reserve (near Lydenburg) (3 trees) and fungi were isolated from symptomatic tissue. Samples were also collected from stem wounds on trees in the Sudwala Caves area (10 trees) and Mawewe Nature Reserve (8 trees) and isolations made onto standard artificial media for the culturing of a broad range of fungi. To investigate the possible connection between the observed tree mortality and drought, rainfall data for each area were obtained from the South African Weather Bureau.

\section{Insert Figure 2}

Diseased and dying $P$. angolensis trees (Figure 3) had a range of disease symptoms. These included crown and branch die-back, wood stain and rot (Figure 3), production of epicormic shoots (Figure 3a), lack of fruit and oozing of sap. Basidiomycete fruiting bodies were present on some trees (Figure 3b). Many trees, especially those in the Mawewe 
Nature Reserve, had signs of fire damage. In many cases these fire scars were most severe at the bases of the trees and associated with internal wood rot (Figures $3 \mathrm{c}$ and 3d).

\section{Insert Figure 3}

A total of 199 fungal isolates were obtained from samples collected from diseased and dying trees (Table 1). Isolates were identified based on morphological characters (size, shape and colour of spores, conidiophores and conidiogenous cells) as observed using a Zeiss Axioskop microscope (Carl Zeiss, Germany). Most isolates were of common saprophytes such as species of Candida, Penicillium and Humicola. A number of isolates did not sporulate in culture and are probably basidiomycetes. Common genera and species isolated that could contribute to disease included Lasiodiplodia theobromae, Cytospora spp. and Fusarium spp.

\section{Insert Table 1}

Species of Cytospora, Fusarium and L. theobromae are commonly associated with stress induced decline of trees globally. Lasiodiplodia theobromae is known to cause a variety of tree diseases, including die-back and bluestain (Punithalingam 1980). Inoculation trials in the field on $P$. angolensis trees (Mehl et al. 2010), however, did not demonstrate pathogenicity. However, disease expression following infection by species of the Botryosphaeriaceae, including $L$. theobromae, has been linked to drought stress (Schoeneweiss 1975, Lewis and van Arsdel 1978, Mullen et al. 1991, Ma et al. 2001, Desprez-Loustau et al. 2006). The genus Cytospora includes species that cause cankers and die-back on infected trees (Adams et al. 2006). Disease expression associated with these species has also been linked to numerous forms of predisposition, including drought 
stress (see Adams et al. 2005, and cited references). Likewise, species of Fusarium cause a variety of plant diseases, including vascular wilts, root rots and damping-off (Bloomberg 1981, Leslie and Summerell 2006).

To ascertain the identity of isolates of Fusarium species obtained in this study and to determine whether any isolates represented $F$. oxysporum, we obtained DNA sequence data for the translation elongation factor $1 \alpha$ gene region for 29 isolates. Standard phylogenetic analysis, including parsimony analysis, was done as described for the Botryosphaeriaceae by Mehl et al. (2010). Fusarium isolates grouped into five clades (total isolates collected in brackets), namely the F. oxysporum (5), F. equiseti (13), F. solani (5), F. graminearum (3), and Gibberella fujikuroi (3) clades (data not shown). Most of the isolates grouping in the $F$. oxysporum clade were obtained from stem wounds while most of the isolates obtained from diseased plant tissue grouped into the $F$. equiseti clade. Fusarium equiseti is known to colonize damaged or senescent plant tissues (Leslie and Summerell 2006) and has been associated with wilt and decline of date palm in Iraq (Abbas et al. 1991). However, F. equiseti is primarily a saprophyte or secondary invader of diseased plant tissues (Leslie and Summerell 2006), arguing against a role in facilitating disease of $P$. angolensis.

\section{Possible contributing factors}

A review of the rainfall data for the sampled areas showed that rainfall was probably a principal factor in decline of $P$. angolensis. Die-back and death of trees was not immediate, but occurred several years after drought, which is typical for stress-related diseases (McDowell et al. 2008 and references cited therein). Stress resulting from drought predisposes trees to attack from other biotic agents, including insects and fungi, and weakens them, increasing their vulnerability to subsequent periods of drought (Bréda et al. 
2006, McDowell et al. 2008). Other biotic agents have been noted such as mistletoes (Loranthus spp.) in the crowns of $P$. angolensis trees dying from mukwa disease (Boaler 1966, Orpen 1982, Vermeulen 1990) and other symptoms such as black spots on the leaves, fungal fruiting bodies and lichens were frequently seen in Krynauw's (2000) study area.

The shallow root system of $P$. angolensis (Geldenhuys 1977), particularly when in competition with a dense grass or shrub layer, undoubtedly contributes to susceptibility to drought and disease development, when annual rainfall is lower than $500 \mathrm{~mm}$. A deep, dense and ramified root system, absent in $P$. angolensis, is known to confer drought tolerance in trees by providing access to both larger reserves of water already present between soil particles, as well as to the water table which may be several layers deep (Bréda et al. 2006). A lack of soil water in the upper soil horizon and the resultant unfavourable dry soil conditions explain the production of epicormic shoots by $P$. angolensis trees suffering from mukwa disease (Piearce 1979). Epicormic shoot production indicates degeneration of feeder roots and mycorrhizae (Manion 1991, Jurskis 2005) and was also observed in our field studies. Drought-like conditions in Mawewe Nature Reserve, Pretoriuskop and Bushbuckridge (Figure 4) in 1993/4 could thus have influenced the disease noted by Krynauw (1998) in South Africa. Several subsequent periods of drought in the years 2002-5 could similarly have contributed to the disease problem we observed during 2005 and 2006 in Mawewe Nature Reserve, Pretoriuskop, Bushbuckridge and Buffelskloof Nature Reserve (Figure 4).

\section{Insert Figure 4}

In most areas where sampling occurred, fire management was not practised. Burning in these areas would suppress competition that $P$. angolensis trees face from neighbouring 
vegetation (Boaler 1966, Von Breitenbach 1973, Vermeulen 1990). Fire also suppresses bush encroachment, a phenomenon where the density of woody plants present, in the form of a thicket of fire-sensitive species (Geldenhuys 1977), progressively increases (Scholes and Archer 1997 and references cited therein). Both the crowns and roots of neighbouring trees and grasses compete with $P$. angolensis for resources including sunlight, soil moisture, soil nutrients and space (Boaler 1966, Orpen 1982, Vermeulen 1990). Both soil nutrients and moisture are concentrated in the upper soil horizon or topsoil (Scholes and Archer 1997). It is, therefore, not surprising that most of the root biomass of both trees and grasses is confined here (Jackson et al. 1996). It is also known that grass roots predominate and outnumber tree roots at these shallow levels (Scholes and Walker 1993). Consequently, competition for these resources is exacerbated by the shallow root system in both mature trees and developing seedlings of $P$. angolensis (Geldenhuys 1977). This competition can influence tree seedling recruitment and regeneration and is heightened in times of drought, probably contributing to the development of disease.

Fire management impacts positively on tree seedling recruitment and regeneration of $P$. angolensis (Boaler 1966, Geldenhuys 1977). Recruitment of seedlings is necessary to sustain populations of $P$. angolensis (Desmet et al. 1996). Low recruitment rates were noted by Krynauw $(1998,2000)$. It is known that developing tree seedlings initially obtain moisture at shallower depths than grasses but at later stages of development they cooccur at the same levels and compete with grass roots (Weltzin and McPherson 1997). Root nodulation of $P$. angolensis seedlings enables nitrogen fixation (Boaler 1966) but is energy-demanding and can be limited by the availability of carbon (Vitousek and Howarth 1991, Sprent 1999, Cramer et al. 2010). Consequently the introduction of fire can enable and promote nodulation by suppressing and removing neighbouring vegetation competing for energy and carbon. Fire also releases nutrients such as phosphorus and nitrogen so that they are readily available to persisting vegetation, including seedlings and mature 
trees of $P$. angolensis, thereby promoting nitrogen fixation (Reiners 1981, Vitousek and Howarth 1991). In this regard, very little phosphorus is lost through volatilization or leaching from soil (Certini 2005), both during and after a fire. Instead, organic phosphorus is converted to orthophosphates (Cade-Menun et al. 2000, Certini 2005), increasing the levels of phosphorus available to plants (Serrasolsas and Khanna 1995, Certini 2005). In contrast, nitrogen-containing compounds are transformed during fire via two steps: initially free amino acids and amino groups $\left(\mathrm{NH}_{2}\right)$ are removed, subsequently amide- $\mathrm{N}$ is converted to heterocyclic aromatic compounds such as pyrimidine, pyrroles, imidazoles, indoles and carbazoles (Knicker et al. 1996, Certini 2005). Additionally, inorganic ammonium $\left(\mathrm{NH}_{4}{ }^{+}-\mathrm{N}\right)$ and nitrate $\left(\mathrm{NO}_{3}{ }^{-}-\mathrm{N}\right)$ are generated during a fire, with some of the ammonium converted to nitrate some time after the fire (a process known as nitrification) (Covington and Sackett 1992, Certini 2005). The two forms have different destinies: nitrate is leached down while ammonium is retained by the soil, being adsorbed by minerals and organic matter (Mroz et al. 1980, Certini 2005).

Fire damage and fire scars represent possible contributing factors in $P$. angolensis decline and death. Fire is particularly important for $P$. angolensis. Both fire and the clearing of vegetation for cultivation remove competing plant species that adversely affect the growth and development of $P$. angolensis (Boaler 1966, Von Breitenbach 1973). "Cold fires" (450 ${ }^{\circ} \mathrm{C}$ lasting $30 \mathrm{~s}$ or less), as already mentioned, enable and promote germination of seedlings by burning off wings and bristles of fruit and removing the grassy layer, allowing the enclosed seed to encounter water during an ensuing rainfall (Von Breitenbach 1973, van Daalen 1991). Fire damage to the boles of trees can occur, possibly due to an accumulation of litter, grass and thicket (fuel) at the base of trees (Geldenhuys 1977), resulting in attack by woodborers and fungi (Schoeman 1982, Vermeulen 1990). After a "hot" fire $\left(450^{\circ} \mathrm{C}\right.$ lasting $90 \mathrm{~s}$ or more) (van Daalen 1991), this debris smolders and the sustained heat can contribute to, if not cause, the observed damage of the stem (Braam 
van Wyk, pers. comm.). Hot fires, as a result of fuel load, can also influence the nutrient composition of soil. During hot fires, soil $\mathrm{pH}$ increases firstly as a result of ash deposition (Arocena and Opio 2003, Certini 2005), and secondly due to the denaturation of organic acids (Certini 2005). This results in phosphorus binding to calcium minerals or precipitating as calcium phosphate (Certini 2005).

Some of the trees observed in this study were ring-barked, probably by porcupines that gnawed the base, exposing the underlying wood to damage by fire as well as providing entry sites for pathogens such as Ganoderma spp. (Yeaton 1988, Shackleton 2002). Although ring-barking by porcupines during periods of drought has been noted (Shackleton 2002), a number of single points of fire-damaged wood were observed in this study (not shown). These single points suggest a fire intense enough to penetrate through to the underlying wood, scarring and damaging it, regardless of size or diameter. The lack of fire management would contribute to the buildup of fuel for such a fire, although the effects of porcupines could ultimately contribute to the damage and mortality observed.

It is recommended that fire be applied biannually just before the annual rainfall season (Geldenhuys 1977) to maintain populations of $P$. angolensis and to enhance recruitment (Geldenhuys 2005) as annual burning adversely affects developing seedlings until the suffrutex root system has fully developed (Groome 1955, Boaler 1966, Högberg 1986). Field observations indicate that fires that occur in areas where biannual burning is not practised, are inordinately hot for the sustainable growth of mature trees and can inhibit recruitment of seedlings and saplings. Previous studies support these findings. In areas where biannual burning was not practised, a thicket of woody species developed that inhibited $P$. angolensis recruitment and fires that subsequently occurred were so intense that they damaged trees severely by burning the phloem and xylem (van Wyk et al. 1993). In addition, these "hot fires" can destroy both seedlings and saplings (van Daalen 1991, 
Banda et al. 2006) and the damage to stems and roots of mature trees, especially shallowrooted trees, can easily enable rot fungi to invade burnt tissues and commence heart rot. Wounds created by fires are further exacerbated by drought conditions (Desprez-Loustau et al. 2006) and provide entry points for fungi responsible for heart rot and disease (Roux et al. 2004, 2005, Chungu et al. 2007).

Regular biannual application of fire also likely promotes the health of $P$. angolensis. Heat resulting from fire is known to inhibit and suppress weed plants and seeds, and is antimicrobial against fungi, bacteria, nematodes and insects (Hardison 1976). Smoke emanating from a fire and from smoldering material is also antimicrobial; inhibiting spore germination, mycelial growth and plant infection (Parmeter and Uhrenholdt 1975). Neighbouring vegetation such as grasses, weeds and other trees, can act as alternate hosts for pathogens of $P$. angolensis, and so their removal by fire impacts positively on the species. Regular application also minimizes the risk of fuel buildup which can lead to runaway fires hazardous to humans. In addition, application of fire can promote and safeguard the health of livestock, particularly in Mawewe Nature Reserve, by eliminating dead and senescent leaves and plant material that can accommodate mycotoxic fungi (Hardison 1976).

Fire aids pruning of side branches and multiple, secondary stems of $P$. angolensis trees (Boaler 1966, Orpen 1982, Vermeulen 1990). A lack of fire can result in poor growth form, a common field observation (Figures $5 a$ and $5 b$ ). In fact, the umbrella-like form of mature, healthy $P$. angolensis trees (Figure 5c) was virtually absent in all the areas where diseased trees occurred. As the species is light-demanding (Boaler 1966, Orpen 1982, Vermeulen 1990), lower branches shaded by newer branches higher up, progressively die (Boaler 1966, Vermeulen 1990). As the branches break off, they can provide entry points for rot fungi. If the branch partially breaks off, the remainder can become encased in the 
bark, serving as a residual entry point for rot fungi. Consequently, if side branches and multiple stems are not pruned or burnt off when branches are small enough to enable active bark recovery, then their presence can contribute to die-back and death of trees. In Acacia mangium, the presence of multiple stems results in "intra-stem competition" and a reduced height and diameter of the main stem (Beadle et al. 2007). Thus, multiple stems in $P$. angolensis could result in premature death due to other neighbouring trees overshadowing the light-demanding individuals of the species. Apart from these obvious health benefits to $P$. angolensis trees, pruning also has commercial importance: it can be used to correct stem defects (Boaler 1966, Vermeulen 1990, Geldenhuys 2005) and can result in an increased length of planks and logs (Boaler 1966, Vermeulen 1990) as well as a trunk increase of $20-25 \%$ (Groome et al. 1957, Vermeulen 1990).

\section{Insert Figure 5}

\section{CONCLUSIONS}

A number of factors noted in this review most likely impact on the health of $P$. angolensis trees. Drought has been implicated in the disease of these trees in both Zambia and South Africa. Rainfall datasets gathered from these areas indicate that reports of die-back and death of trees can be correlated with several years of drought, either intermittent or sustained over several years. The effect of these drought periods is observed in subsequent years, when trees begin to die back and decline. Along with $P$. angolensis, other tree species in the same area are affected by disease. The symptoms of mukwa disease noted in this review, along with these facts, argue that the primary cause of the disease is most likely not biotic.

Together with rainfall, fire is a crucial factor impacting on the health and sustainability of $P$. 
angolensis. Fires enable germination, regeneration, nitrogen fixation, and nodule formation in $P$. angolensis, ensuring that seedlings and saplings are not impeded during growth. Fires also suppress neighbouring plant and tree species that compete with $P$. angolensis for soil nutrients, moisture, space and sunlight. Competition for these is likely elevated during times of drought and predisposes $P$. angolensis individuals to stress. Both heat and smoke resulting from fires can promote health of $P$. angolensis. Consequently, the interaction between adverse environmental conditions or improper management in combination with the biology of $P$. angolensis, likely predisposes individuals of the species to disease.

The timing of application of fire is critical. An annual fire inhibits regeneration of $P$. angolensis by negatively affecting recruitment of seedlings. A fire applied too infrequently has a similar effect, but can also damage mature trees, contributing to subsequent dieback and disease of stressed $P$. angolensis trees.

Both mukwa disease and the symptoms on $P$. angolensis trees noted in South Africa are probably the result of fire exclusion and improper fire management, but data from the field will be needed to either confirm or refute this. Indeed, field observations in the course of this study would have benefited from further information regarding the ecology of affected diseased trees to determine whether trends exist and if they are consistent. These observations would add weight to findings or introduce new data to be considered. Data with regard to the age of trees, the vegetation surrounding affected trees, grass cover and tree interaction as well as whether these are due to fire frequency and/or grazing, the degree of competition from neighbouring vegetation, data regarding rainfall including frequency and timing are all factors that would have to be considered in future studies. This review, consequently, is superficial in investigating the cause and reasons for the observed decline of $P$. angolensis, relying mainly on a review of the literature and drawing 
upon previous data to support observations. However, it is the first to consider the broader problem and should be seen as motivation for future studies.

In the light of global climate change, die-back and death of $P$. angolensis is indeed a cause for concern. It is likely that droughts in areas where the species occurs will continue to increase in frequency and intensity, adding to conservation concerns. At present, reserve managers and nature conservation agencies are advised to practise biannual burning, just prior to the annual rainfall season in areas where $P$. angolensis occurs. Fuel load is an important factor to consider in fire management and can be affected by grazing and clearing of litter, grass and thicket. An optimal fuel load will result in a cold fire that will encourage regeneration of the species, rather than one of high intensity resulting in damage to stems and fire scars, prompting rot to develop. Natural side-branch pruning should also be done at an early age on small branches and secondary stems where necessary and wounding of trees should be prevented and prosecuted where possible.

\section{Acknowledgements}

We thank the DST/NRF Centre of Excellence in Tree Health Biotechnology (CTHB) for financial support and the South African Weather Bureau for providing rainfall data necessary for this study. We thank Mr. Dennis Owen and Dr. Andrew Morris for their assistance in the editorial process as well as two anonymous reviewers for valuable comments on the manuscript. The late Sonette Krynauw as well as Shadow Headzane, Phumzile Khosa (Mpumalanga Parks Board, Nelspruit and Malelane, South Africa), John Burrows (Buffelskloof Nature Reserve, Lydenburg, South Africa) and numerous of our colleagues/fellow students are also thanked for their assistance in the field with collections and sampling. We also acknowledge Mr. Chris de Jager (Department Plant Production and Soil Science, University of Pretoria, Pretoria, South Africa) for helpful discussion on soil 
chemistry both during and after fire. This paper is dedicated to the memory of Sonette Krynauw (1962-2010) who prompted this study, principally through her initial investigation of the death and die-back of kiaat trees in Mawewe Nature Reserve.

\section{REFERENCES}

Abbas HK, Mouhi MN, Al-Roubaie JT, Hama NN and El-Bahadli AH (1991) Phomopsis phoenicola and Fusarium equiseti, new pathogens on date palm in Iraq. Mycological Research 95: 509

Adams GC, Roux J and Wingfield MJ (2006) Cytospora species (Ascomycota, Diaporthales, Valsaceae): introduced and native pathogens of trees in South Africa. Australian Plant Pathology 35: 521-548

Adams GC, Wingfield MJ, Common R and Roux J (2005) Phylogenetic relationships and morphology of Cytospora species and related teleomorphs (Ascomycota, Diaporthales, Valsaceae) from Eucalyptus. Studies in Mycology 52: 1-144

Anderson RC, Gardner DE, Daehler CC and Meinzer FC (2002) Dieback of Acacia koa in Hawaii: Ecological and pathological characteristics of affected stands. Forest Ecology and Management 162: 273-286

Anonymous (1967) World Weather Records (1951-1960), Vol. 5: Africa. United States Department of Commerce Environmental Science Services Administration, Washington D.C.

Anonymous (1973) Dieback in mukwa (Pterocarpus angolensis) in Matabeleland. Research Newsletter 7: 6

Anonymous (1979) World Weather Records (1961-1970), Vol. 5: Africa. Environmental Science Services Administration, Washington D.C.

Anonymous (1987) World Weather Records (1971-1980), Vol. 5: Africa. Environmental Science Services Administration, Washington D.C. 
Arocena JM and Opio C (2003) Prescribed fire-induced changes in properties of subboreal forest soils. Geoderma 113: 1-16

Banda T, Schwartz MW and Caro T (2006) Effects of fire on germination of Pterocarpus angolensis. Forest Ecology and Management 233: 116-120

Beadle C, Barry K, Hardiyanto E, Irianto R, Junarto, Mohammed C and Rimbawanto A (2007) Effect of pruning Acacia mangium on growth, form and heart rot. Forest Ecology and Management 238: 261-267

Bloomberg WJ (1981) Diseases caused by Fusarium in forest nurseries. In: Nelson PE, Toussoun TA and Cook RJ (Eds.) Fusarium: Diseases, Biology and Taxonomy. The Pennsylvania State University Press, University Park and London, pp. 178-187

Boaler SB (1966) The ecology of Pterocarpus angolensis D. C. in Tanzania. Her Majesty's Stationery Office, London, $128 \mathrm{pp}$

Bradley P and Dewees P (1993) Indigenous woodlands, agricultural production and household economy in the communal areas. In: Bradley PN and McNamara K (Eds.) Living with Trees: Policies for Forestry Management in Zimbabwe. World Bank Technical Paper 210, World Bank, Washington D.C., pp. 63-157

Bréda N, Huc R, Granier A and Dreyer E (2006) Temperate forest trees and stands under severe drought: a review of ecophysiological responses, adaptation processes and long-term consequences. Annals of Forest Science 63: 625-644

Burke A (2006) Savanna trees in Namibia - factors controlling their distribution at the arid end of the spectrum. Flora 201: 189-201

Cade-Menun BJ, Berch SM, Preston CM and Lavkulich LM (2000) Phosphorus forms and related soil chemistry of Podzolic soils on northern Vancouver Island II: The effects of clear-cutting and burning. Canadian Journal of Forest Research 30:17261741 (as cited by Certini 2005)

Calvert GM (1972) Mukwa disease: Final report. Rhodesia Forestry Commission, 32 pp (as cited by Piearce 1979) 
Calvert GM (1986) Growth summaries, sample plot 1, Gwaai Forest. In: Piearce GD (Ed.) The Zambezi Teak Forests: Proceedings of the First International Conference on the Teak Forests of Southern Africa, 18-24 March 1984, Livingstone, Zambia, pp. 198201

Caro TM, Sungula M, Schwartz MW and Bella EM (2005) Recruitment of Pterocarpus angolensis in the wild. Forest Ecology and Management 219: 169-175

Certini G (2005) Effects of fire on properties of forest soils: a review. Oecologia 143: 1-10

Chungu D, Muimba-Kankolongo A, Roux J and Malambo FM (2007) Bark removal for medicinal use predisposes indigenous forest trees to wood degradation in Zambia. Southern Hemisphere Forestry Journal 69: 157-163

Clarke J, Cavendish W and Coote C (1996) Rural households and miombo woodlands: use, value and management. In: Campbell B (Ed.) The Miombo in Transition: Woodland and Welfare in Africa. Centre for International Forestry Research, Bogor, Indonesia, pp. 101-135

Coates Palgrave K (1977) Trees of southern Africa. Struik Publishers (Pty) Ltd., Cape Town, South Africa, $959 \mathrm{pp}$

Covington WW and Sackett SS (1992) Soil mineral nitrogen changes following prescribed burning in ponderosa pine. Forest Ecology and Management 54: 175-191

Cramer MD, Van Cauter A and Bond WJ (2010) Growth of $\mathrm{N}_{2}$-fixing African savanna Acacia species is constrained by below-ground competition with grass. Journal of Ecology 98: 156-167

Desprez-Loustau M-L, Marçais B, Nageleisen L-M, Piou D and Vannini A (2006) Interactive effects of drought and pathogens in forest trees. Annals of Forest Science 63: $597-612$

Desmet PG, Shackleton CM and Robinson ER (1996) The population dynamics and lifehistory attributes of a Pterocarpus angolensis DC. population in the Northern Province, South Africa. South African Journal of Botany 62: 160-166 
Geary TF (1972) Mukwa blight in central Africa. Plant Disease Reporter 56: 820-821

Geldenhuys CJ (1977) The effect of two different regimes of annual burning on two woodland communities in Kavango. South African Forestry Journal 103: 32-42

Geldenhuys CJ (2005) Basic guidelines for silviculture and forest management practices in Mozambique. Report No. FW-04/05. Forestwood CC., 83 pp

Gordon TR and Martyn RD (1997) The evolutionary biology of Fusarium oxysporum. Annual Review of Phytopathology 35: 111-128

Groome JS (1955) Muninga (Pterocarpus angolensis D. C.) in the western province of Tanzania. East Africa Agriculture and Forestry Journal 21: 130-137 (as cited by Boaler 1966)

Groome JS, Lees HMN and Wigg LT (1957) A summary of information on Pterocarpus angolensis Part I. Forestry Abstracts 18: 3-8

Hardison JR (1976) Fire and flame for plant disease control. Annual Review of Phytopathology 14: 355-379

Hines DA and Eckman K (1993) Indigenous multipurpose trees of Tanzania: uses and economic benefits for people. Cultural Survival Canada and Development Services Foundation of Tanzania, Ottawa, Ontario, Canada. Available at http://www.betuco.be/agroforestry/Indigenous\%20Multipurpose\%20trees\%20of\%20T anzania\%20FAO.pdf, [accessed on 14 March 2010]

Högberg P (1986) Nitrogen-fixation and nutrient relations in savanna woodland trees (Tanzania). Journal of Applied Ecology 23: 675-688

Högberg P (1992) Mycorrhizas in African miombo savanna woodlands. In: Read DJ, Lewis DH, Fitter AH and Alexander IJ (Eds.) Mycorrhizas in Ecosystems. CAB International, Oxon, U.K., pp. 382-383

Holdo RM and Timberlake J (2008) Rooting depth and above-ground community composition in Kalahari sand woodlands in western Zimbabwe. Journal of Tropical Ecology 24: 169-176 
Jackson RB, Canadell J, Ehleringer JR, Mooney HA, Sala OE and Schulze ED (1996)

A global analysis of root distributions for terrestrial biomes. Oecologia 108: 389-411

Jacobi JD, Gerrish G and Mueller-Dombois D (1983) 'Ōhia'a dieback in Hawai'i:

vegetation changes in permanent plots. Pacific Science 37: 327-337

Jurskis V (2005) Eucalypt decline in Australia, and a general concept of tree decline and dieback. Forest Ecology and Management 215: 1-20

Knicker H, Almendros G, González-Vila FJ, Martin F and Ludemann H-D (1996) ${ }^{13}$ Cand ${ }^{15} \mathrm{~N}-\mathrm{NMR}$ spectroscopic examination of the transformation of organic nitrogen in plant biomass during thermal treatment. Soil Biology and Biochemistry 28: 1053-1060

Krynauw S (1998) Report on the feasibility of the proposed utilization of kiaat

(Pterocarpus angolensis D. C.) on Mawewe. Mpumalanga Parks Board Research and Development, Lydenburg, South Africa, 13 pp

Krynauw S (2000) An evaluation of the feasibility of the proposed harvesting of Pterocarpus angolensis on Mawewe Nature Reserve. In: Seydack AHW, Vermeulen WJ and Vermeulen C (Eds.) Towards Sustainable Management Based on Scientific Understanding of Natural Forests and Woodlands: Proceedings of the Natural Forests and Savanna Woodlands Symposium II, 5-9 September 1999, Knysna, South Africa, pp. 212-215

Lawton RM (1978) A study of the dynamic ecology of Zambian vegetation. Journal of Ecology 66: 175-198

Leslie JF and Summerell BA (2006) The Fusarium Laboratory Manual. Blackwell Publishing, lowa, U.S.A., 388 pp

Lewis Jr. R and van Arsdel EP (1978) Vulnerability of water-stressed sycamores to strains of Botryodiplodia theobromae. Plant Disease Reporter 62: 62-63

Lombard L, Bogale M, Montenegro F, Wingfield BD and Wingfield MJ (2008) A new bark canker disease of the tropical hardwood tree Cedrelinga cateniformis in Ecuador. Fungal Diversity 31: 73-81 
Lowore J (1993) Growing indigenous trees: Mlombwa - Pterocarpus angolensis - an endangered fine hardwood. Forestry Research Institute of Malawi (FRIM) Newsletter 71: 4

Ma Z, Morgan DP and Michailides TJ (2001) Effects of water stress on Botryosphaeria blight of pistachio caused by Botryosphaeria dothidea. Plant Disease 85: 745-749

Manion PD (1991) Tree Disease Concepts (2nd edn). Prentice-Hall Inc., New Jersey, 399 pp (as cited in Jurskis 2005)

McDowell N, Pockman WT, Allen CD, Breshears DD, Cobb N, Kolb T, Plaut J, Sperry J, West A, Williams DG and Yepez EA (2008) Mechanisms of plant survival and mortality during drought: why do some plants survive while others succumb to drought? New Phytologist 178: 719-739

Mehl JWM, Slippers B, Roux J and Wingfield MJ (2010). Botryosphaeriaceae associated with Pterocarpus angolensis (kiaat) in South Africa. Mycologia (in press)

Mroz GD, Jurgensen MF, Harvey AE, Larsen MJ (1980) Effects of fire on nitrogen in forest floor horizons. Soil Science Society of America Journal 44: 395-400

Mueller-Dombois D (1983) Canopy dieback and successional processes in Pacific forests. Pacific Science 37: 317-325

Mueller-Dombois D (1986) Perspectives for an etiology of stand-level dieback. Annual Review of Ecology and Systematics 17: 221-243

Mullen JM, Gilliam CH, Hagan AK and Morgan-Jones G (1991) Canker of dogwood caused by Lasiodiplodia theobromae, a disease influenced by drought stress or cultivar selection. Plant Disease 75: 886-889

Munyanziza E and Oldeman RAA (1995) Pterocarpus angolensis D. C.: field survival strategies, growth, root pruning and fertilization in the nursery. Fertilizer Research 40 : $235-242$

Mushove PT (1996) Population dynamics of Pterocarpus angolensis D. C. stands growing on Kalahari sands. In: Mushove PT, Shumba EM and Matose F (Eds.) Sustainable 
Management of Indigenous Forests in the Dry Tropics: Proceedings of an

International Conference, 28 May-1 June 1996, Kadoma, Zimbabwe. Forestry

Commission, Harare, pp. 155-167

Oppelt AL, Kurth W, Jentschke G and Godbold DL (2005) Contrasting rooting patterns of some arid-zone fruit tree species from Botswana - I. Fine root distribution. Agroforestry Systems 64: 1-11

Orpen FL (1982) A monograph on Pterocarpus angolensis. Official file A20/5/3

Pterocarpus, Department of Water Affairs and Forestry, Pretoria, South Africa (as cited by Vermeulen 1990)

Parmeter Jr JR and Uhrenholdt B (1975) Some effects of pine-needle or grass smoke on fungi. Phytopathology 65: 28-31

Piearce GD (1979) A new vascular wilt disease and its relationship to widespread decline of Pterocarpus angolensis in Zambia. Pest Articles and News Summaries (PANS) 25: $37-45$

Piearce GD (1983) Wilt disease of mukwa (Pterocarpus angolensis) associated with Fusarium oxysporum in Zambia. In: Abstracts of the 4th International Congress of Plant Pathology, 17-24 August 1983, Melbourne, Australia. (as cited by Piearce 1986)

Piearce GD (1986) Tree diseases and disorders in the Zambezi teak forests. In: Piearce GD (Ed.) The Zambezi Teak Forests: Proceedings of the First International Conference on the Teak Forests of Southern Africa, 18-24 March 1984, Livingstone, Zambia, pp. 239-257

Punithalingam E (1980) Plant diseases attributed to Botryodiplodia theobromae Pat. J. Cramer, Vaduz, $113 \mathrm{pp}$

Reiners WS (1981) Nitrogen cycling in relation to ecosystem succession: a review.

Ecological Bulletins 33: 507-528 (as cited by Vitousek and Howarth 1991)

Roux J, Geldenhuys CJ, Meke G, Nguvulu C, Malambo F, Rau D, Kamgan NG and 
Heath RN (2005) Fungi infecting medicinal bark wounds in Southern Africa. In: Trees for Health Forever: Implementing Sustainable Medicinal Bark Use in Southern Africa,

SADC Regional Workshop, 1-3 November 2005, Johannesburg, pp. 21-31

\section{Roux J, Heath RN, Meke G, Nguvulu C, Malambo F, Geldenhuys CJ and Wingfield}

MJ (2004) Fungi associated with bark wounds on indigenous African trees.

Proceedings of the American Phytopathological Society Meeting, July 31-August 4, Anaheim, California. Phytopathology 94: S89

Rutherford MC (1983) Growth rates, biomass and distribution of selected woody plant roots in Burkea africana-Ochna pulchra savanna. Vegetatio 52: 45-63

Schoeman J (1982) Official correspondence. Official file A20/5/3 Pterocarpus,

Department of Water Affairs and Forestry, Pretoria (as cited by Vermeulen 1990)

Schoeneweiss DF (1975) Predisposition, stress, and plant disease. Annual Review of

Phytopathology 13: 193-211

Scholes RJ and Archer SR (1997) Tree-grass interactions in savannas. Annual Review of Ecology and Systematics 28: 517-544

Scholes RJ and Walker BH (1993) An African savanna: synthesis of the Nylsvley study. Cambridge University Press, Cambridge, UK, 306 pp

Schwartz MW, Caro TM and Banda-Sakala T (2002) Assessing the sustainability of harvest of Pterocarpus angolensis in Rukwa Region, Tanzania. Forest Ecology and Management 170: 259-269

Serrasolsas I and Khanna PK (1995) Changes in heated and autoclaved forest soils of S.E. Australia II: Phosphorus and phosphatase activity. Biogeochemistry 29: 25-41

Shackleton CM (2002) Growth patterns of Pterocarpus angolensis in savannas of the South African lowveld. Forest Ecology and Management 166: 85-97

Simute S, Phiri CL and Tengnäs B (1998) Agroforestry extension manual for eastern Zambia. Regional Land Management Unit (RELMA/Sida), Nairobi, Kenya. Available at: 
http://www.worldagroforestry.org/sites/relma/Relmapublications/PDFs/TH17\%20East er\%20Zambia\%201-10.pdf, [accessed on 14 March 2010]

Sprent JI (1999) Nitrogen fixation and growth of non-crop legume species in diverse environments. Perspectives in Plant Ecology, Evolution and Systematics 2: 149-162

Steenkamp C (1999) South Africa's woodcarving industry. TRAFFIC Bulletin 18: 11-20

Strang RM (1974) Some man-made changes in successional trends on the Rhodesian highveld. Journal of Applied Ecology 11: 249-263

van Daalen JC (1991) Germination of Pterocarpus angolensis seed. South African Forestry Journal 158: 33-36

van Wyk M, Campbell BM, Calvert GM and Piearce GD (1993) Mukwa dieback in the state forests of western Zimbabwe. In: Piearce GD and Gumbo DJ (Eds.) The Ecology and Management of Indigenous Forests in Southern Africa: Proceedings of an International Symposium, 27-29 July 1992 Victoria Falls, Zimbabwe, pp. 387-401 van Wyk P (1972) Plants of the Kruger National Park part 4: Pterocarpus angolensis (kiaat, bloodwood). Custos 1: 47-48

Vermeulen WJ (1990) A monograph on Pterocarpus angolensis. SARRCUS Standing Committee for Forestry, Department of Environmental Affairs, Water Affairs and Forestry, Pretoria, South Africa, $133 \mathrm{pp}$

Viljoen AJ (1995) The influence of the 1991/92 drought on the woody vegetation of the Kruger National Park. Koedoe 38: 85-97

Vitousek PM and Howarth RW (1991) Nitrogen limitation on land and in the sea: How can it occur? Biogeochemistry 13: 87-115

Von Breitenbach F (1973) Pterocarpus angolensis. Trees in South Africa 25: 58-80

Welch JR (1960) Observations on deciduous woodland in the eastern province of Tanganyika. Journal of Ecology 48: 557-573

Weltzin JF and McPherson GR (1997) Spatial and temporal soil moisture resource partitioning by trees and grasses in a temperate savanna, Arizona, USA. Oecologia 
112: $156-164$

White F (1983) The vegetation of Africa: a descriptive memoir to accompany the Unesco/AETFAT/UNSO vegetation map of Africa. Natural Resources Research 20, UNESCO, Paris, $356 \mathrm{pp}$

Yeaton RI (1988) Porcupines, fires and the dynamics of the tree layer of the Burkea africana savanna. Journal of Ecology 76: 1017-1029 
Table 1: Overview of fungi isolated from $P$. angolensis trees in South Africa with locations noted.

Fungus

Location $^{\times}$

Acremonium sp.

BNR, MNR, SCA

Alternaria sp.

MNR

Aspergillus sp.

MNR, SCA

Candida sp.

BNR, MNR, SCA

Chrysosporium sp.

BNR, MNR, SCA

Cylindrocarpon sp.

BNR, MNR, SCA

Cytospora sp.

MNR, SCA

Diplodia alatafructa

BNR, SCA

Fusarium sp.

MNR, SCA

Geotrichum sp.

BNR

Gliocladium sp.

BNR, MNR, SCA

Humicola sp.

BNR, MNR, SCA

Lasiodiplodia crassispora

MNR

L. pseudotheobromae

MNR, SCA

L. theobromae

BNR, MNR

Mycelia sterilia

BNR, MNR, SCA

Myriodontium sp.

MNR

Penicillium sp.

BNR, MNR, SCA 
Rhizopus sp.

${ }^{\star}$ BNR = Buffelskloof Nature Reserve, MNR = Mawewe Nature Reserve, SCA = Sudwala
Staphylotrichum sp.

Trichoderma sp.

Trichosporon sp.

MNR

BNR, MNR, SCA

BNR, MNR, SCA

MNR

Caves area 


\section{List of figures}

Figure 1: Charts of rainfall data from the Livingstone and Bulawayo areas. Mukwa disease reports are denoted by stars above bars.

Figure 2: Map of the sites sampled. The boxed area on the South African map indicates the Mpumalanga Province where samples were collected from. The three sampling sites (Mawewe Nature Reserve, Buffelskloof Nature Reserve, Sudwala Caves area) on the larger map of Mpumalanga Province are denoted by X [South Africa map source: http://upload.wikimedia.org/wikipedia/commons/thumb/b/bc/Map_of_South_Africa_with_ Mpumalanga_highlighted.svg, accessed on 27 September 2009, Mpumalanga Province map source: http://www.stayinsa.co.za/southafrica/mpumalanga_hotels.html, accessed on 27 September 2009]

Figure 3: Disease symptoms observed on $P$. angolensis trees in South Africa. a. Diseased trees in the field. b. Ganoderma fruiting body at the base of a fire-damaged tree. c. Heart rot with evidence of zone lines present. d. Heart rot initiated due to fire damage of the stem.

Figure 4: Rainfall data $(\mathrm{mm})$ for the various areas considered in this study. Weather stations noted are closest to the sites from where we sampled. a) Mawewe Nature Reserve area. b) Pretoriuskop. c) Bushbuckridge area. d) Buffelskloof Nature Reserve area.

Figure 5: Incorrect growth forms of $P$. angolensis due to side branches and secondary stems during field observations $(a, b)$ and correct growth form (c). Correct growth form can 
be obtained through fire management and by manually pruning. Note competing plants at the base of the tree in (a). (c) copyright Geldenhuys (2005). 
Figure 1 
(a)

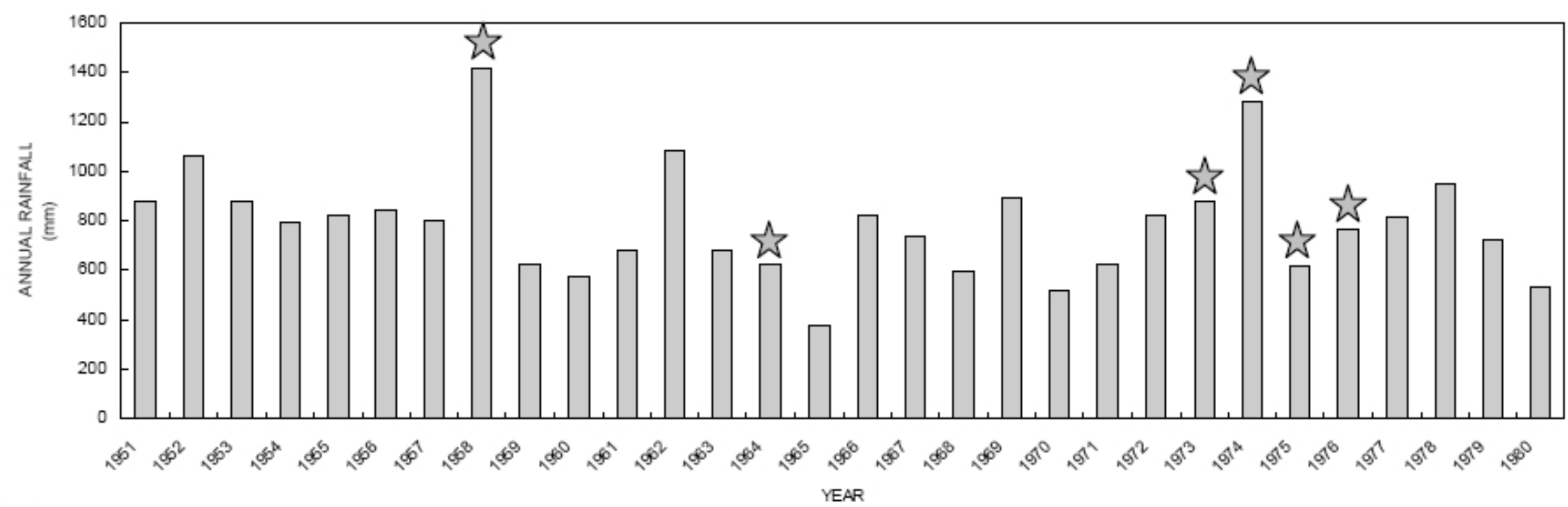

(b)

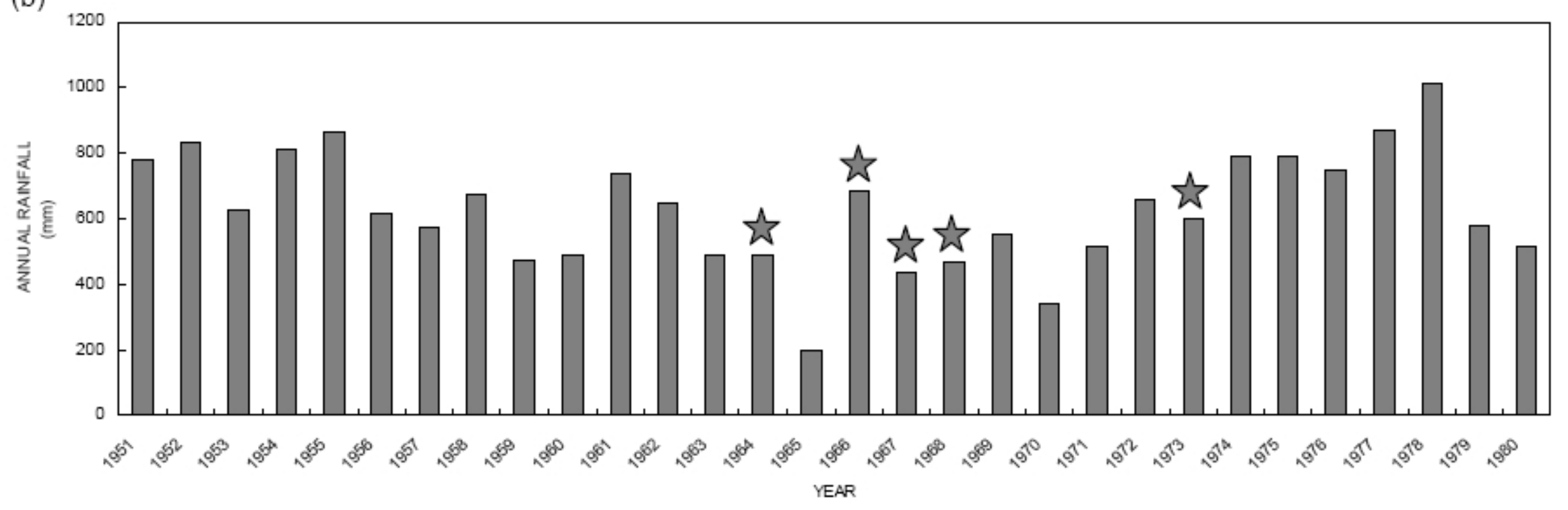


Figure 2 





Figure 3

Figure 4

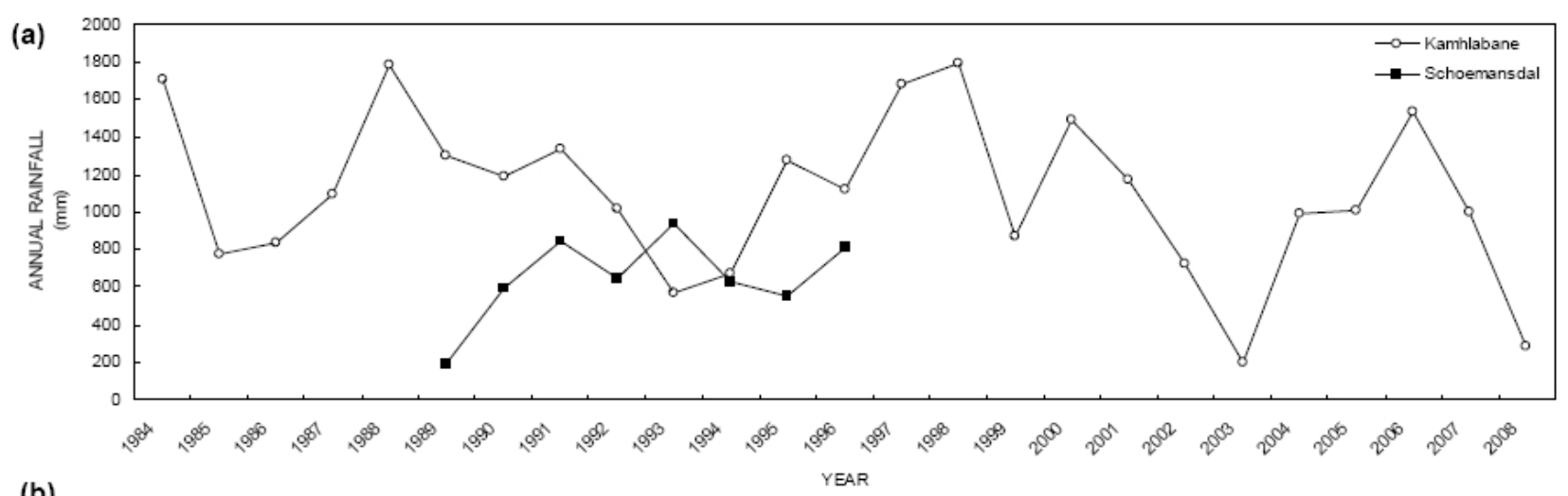

(b)
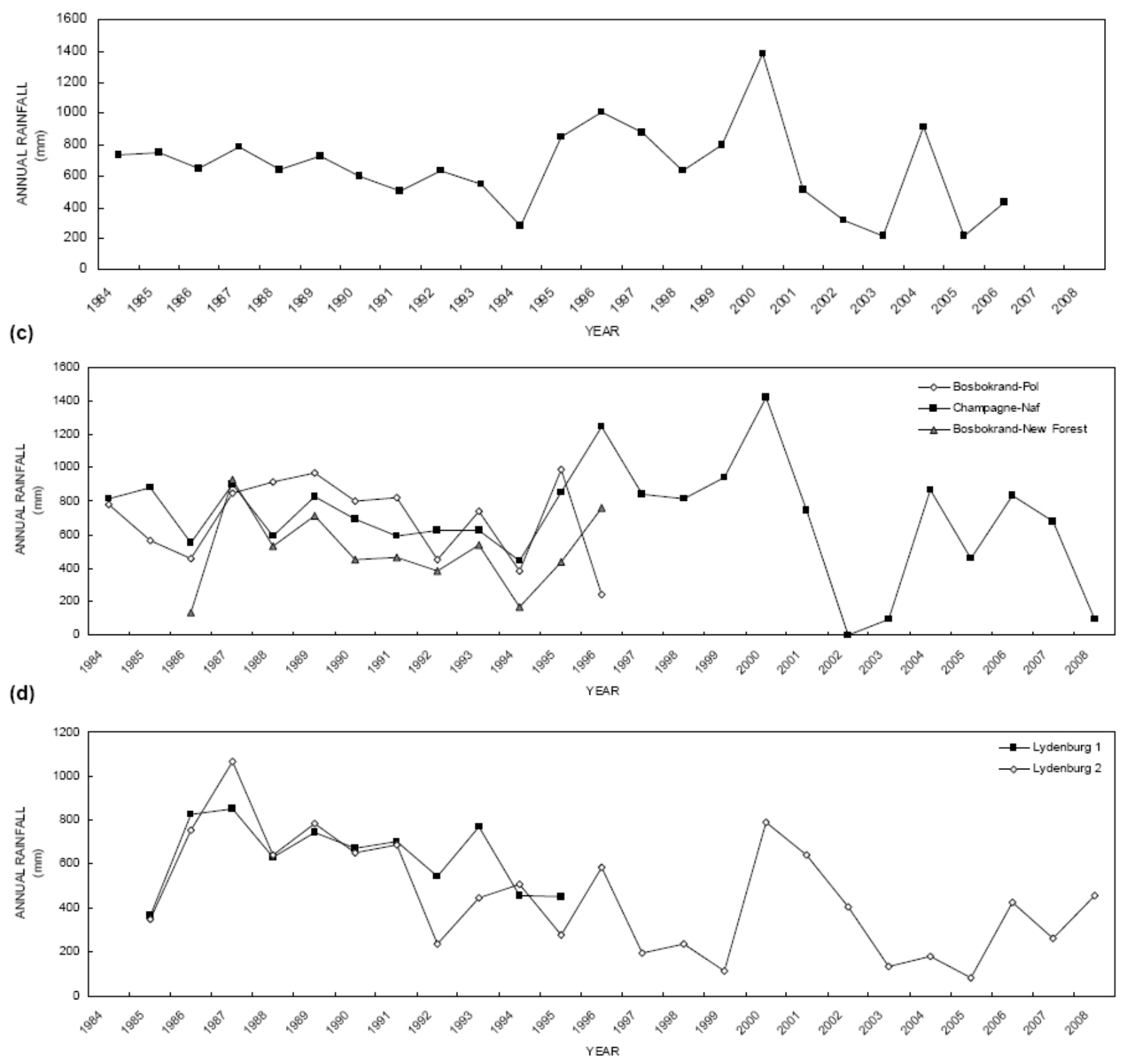
Figure 5
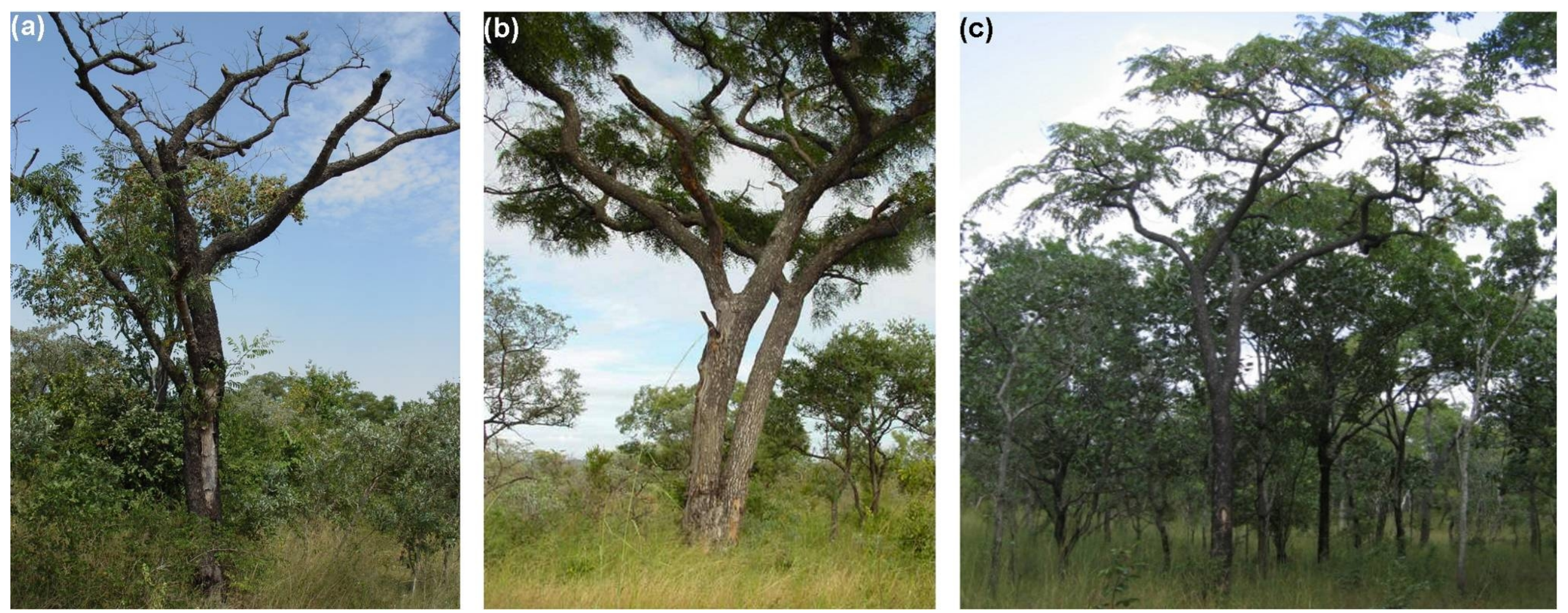